\title{
Personnel Service, Consumption Emotion, and Patronage Intention in Department Stores
}

\author{
Min $\mathrm{Hou}^{1}$, Xiaoding $\mathrm{Wu}^{2} \&$ Zuohao $\mathrm{Hu}^{1}$ \\ ${ }^{1}$ School of Economics and Management, Tsinghua University, Beijing, China \\ ${ }^{2}$ Business School, Jilin University, Changchun, China \\ Correspondence: Min Hou, Room 538 Weilun Building, School of Economics and Management, Tsinghua \\ University, Beijing, China. Tel: 86-186-0199-5670. E-mail: houm@sem.tsinghua.edu.cn
}

Received: January 7, 2013

Accepted: January 17, 2013

Online Published: January 25, 2013

doi:10.5539/ibr.v6n3p6

URL: http://dx.doi.org/10.5539/ibr.v6n3p6

\begin{abstract}
This paper explains customer patronage intention by analyzing the relationships among personnel service, consumption emotion and patronage intention. The findings are as follows: (1) customers' perceptions of the reflection and assurance of personnel service significantly influence their consumption emotion. Reflection and assurance significantly influence happiness, dominance and arousal. However, the influence of reflection is negative, meaning customers who perceive stronger reflection from service personnel feel lower consumption emotion when shopping for relaxation; (2) customers' perceptions of the consumption emotions of happiness and arousal significantly influence their patronage intention. That is, the more happiness and arousal customers feel, the more patronage intention they exhibit; (3) Consumption emotion mediates between personnel service and patronage intention. This research not only improves understanding of customer patronage intention, but also provides management guidance for department store operators.
\end{abstract}

Keywords: personnel service, consumption emotion, patronage intention, department store

\section{Introduction}

The rise of online shopping has affected the operation of physical stores strongly and negatively, including department stores. The shopping habits of customers have changed. Customers browse for merchandise in stores, note the price and item number, and then search online for the same items of clothing, household appliances, cosmetics, and household goods, seeking e-shops that often sell the goods much cheaper (Roland Berger Strategy Consultants, 2010). While managers of department stores are trying to attract customers by enhancing services, improving service personnel management, and upgrading store decorations, the effectiveness of these measures remains unclear. The reality is that many bright and spacious shopping malls attract few customers, and traditional forms of promotion are increasingly ineffective in attracting customers. However, customers continue to patronize department stores. One reason is that customers believe department stores offer lifestyle models and actual shopping experiences; functions that online shopping cannot replace. Therefore, identifying how to enhance the shopping experience and make it unique is important for helping department stores attract customers. Emotions are important to many shopping experiences.

Customer consumption needs have changed from 'job consumption' to 'joy consumption' (Bakewell \& Mitchell, 2003; Tamura, 2007). This study labels the latter 'hedonic shopping'. Hedonic shopping describes shopping motivated not merely by the need to make a purchase, but also for enjoyment. Previous studies emphasized environmental influences, for instance, color (Donovan \& Rossiter, 1982; Bellizzi \& Hite, 1992; Chebat \& Turley, 2005), music (Yalch \& Spangenberg, 1990, 2000; Broekemier, Marquardt, \& Gentry, 2008) and temperature (Chun \& Tamura, 1998; Michon, Chebat, \& Turley, 2005). However, department stores are service-intensive operations in which salespeople interact with customers at different times and across diverse locations. Customers experience more emotions during service consumption when they frequently encounter enthusiastic service personnel (Price, Amould, \& Deibler, 1995). How service personnel behavior affects customers and enables them to experience specific emotions is an important question that previous studies have neglected. On the one hand, while customer satisfaction is fundamental to interpreting customer experience, it cannot explain the failure of satisfied customers to return. On the other hand, researchers interested in the service perspective have focused too much on minor details, such as facial expressions and behavior (Hansen, Sandvik, 
\& Seines, 2002; McColl-Kennedy, Patterson, Smith, \& Brady, 2009). The literature has failed to present practical findings that managers can apply to improve store operations.

To redress these weaknesses of the literature we examine how interactions with service personnel affect customer consumption emotion, and whether the feelings associated with consumption emotion further affect customer patronage intention. We attempt to answer these questions by establishing a relational model of personnel service, consumption emotion and patronage intention, and analyzing the relationships among them. Such modeling and analysis will provide practical guidance to the management of department stores for improving store performance.

\section{Literature Review}

\subsection{Personnel Service}

Research on personnel service remains immature. However, the service encounter and service quality literature includes research on personnel service.

\subsubsection{Personnel Service in Service Encounter Research}

Service encounters involve service production and service consumption, and it can be defined from both perspectives. Specifically, service encounters involve interpersonal interaction between customers and service providers during service delivery, as well as interaction with other customers (Surprenant \& Solomon, 1987). Examples of research adopting a narrow view of service encounters include Interactive Marketing by Kotler (1984) and Moment of Truth by Normann (1984). However, many scholars (Shostack, 1985; Bitner, Booms, \& Tetreault, 1990; Fan, 1999) consider service encounters to refer not only to interactions between customers and service facilities or the physical environment, but also to interpersonal interactions.

Both perspectives consider personnel service an important element in service encounters. Perceptions of personnel service differ among industries because of different levels of customer's involvement in service. Based on customer involvement, Lovelock (1983) classified service industries into three types.

(a) Low connection. Customers seldom interact directly with service providers. Such services normally rely on special tools and equipment, and include information, postal and telecommunications services. Customer requirements are focused on equipment rather than personnel service. Customers only become concerned with personnel service quality when they need service that the equipment cannot perform.

(b) Medium connection. Customers participate in certain stages of service provision. Examples of such services include banks, lawyers, and real estate brokers. Customers of medium connection services are more involved than those of low connection services and so have higher requirements of service providers. However, no standardized service evaluation criteria exist.

(c) High connection. Customers participate in all or most activities during service provision. Examples of such services include department stores, cinemas, public transportation and schools. In high connection services, customer requirements of service providers are much higher than in the previous two types. Customers gradually develop criteria for service evaluation. Darian, Tucci, and Wiman (2001) analyzed customer perceptions of salespeople in electronic stores and found that customers felt strongly about four characteristics: (1) respect for customers, (2) knowledge, (3) responsiveness, and (4) friendliness. These characteristics represent important service attributes that shape customer perceptions.

\subsubsection{Personnel Service in Service Quality Research}

Customer perceptions determine service quality. Therefore, service quality is a complex composite that cannot be measured using service alone. Service quality comprises various elements and requires comprehensive evaluation. Parasuraman, Zeithaml, and Berry $(1985,1991)$ further improved the operationalization of service quality. They researched the determinants and customer perceptions of service quality and identified five fundamental dimensions: (a) tangibility, referring to physical evidence of service, such as service facilities and visible service personnel; (b) reliability, accurate delivery of service; (c) responsiveness, willingness and readiness to provide timely and effective service; (d) assurance, friendliness and competency of service personnel; and (e) empathy, the commitment to sincerely care for customers, learn their real needs, and provide service accordingly.

Although personnel service is not proposed as an independent dimension of service quality, service providers rely on their personnel. The five dimensions described above are closely associated with service personnel activities. Customers measure the five dimensions by assessing the services provided by service personnel, especially in high connection service industries like department stores, hotels and restaurants. 


\subsection{Consumption Emotion}

\subsubsection{Definition of Consumption Emotion}

Numerous scholars have long been attempting to define consumption emotion. One argument suggests that consumption emotion is the psychological response derived from acknowledgement of products and services in consumption experiences (Mano \& Oliver, 1993; Richins, 1997). Consumption emotion, which is a customer affective state and its evolution, describes a feeling that results from using or consuming products and services. Therefore, consumption emotion is dynamic. During consumption, a customer might experience happiness, excitement, satisfaction and other positive emotions, as well as disappointment, anger, sadness, guilt and other negative emotions (Menon \& Dubé, 2000). Baker, Levy, and Grewal (1992) argued that positive emotions and negative emotions, two independent bipolar definitions, do not exist simultaneously. However, emotion is a continuously evolving process characterized by variability, complexity and abstraction. Customer affective state is constantly located between two poles. Customers might experience positive and negative emotions simultaneously during consumption (Westbook \& Oliver, 1991).

After reviewing 28 definitions of consumption emotion in the literature, Plutchik (1980) claimed that they lack consistency and clarity. Hence, some scholars (Ortony, Clore, \& Collins, 1988; Mano \& Oliver, 1993; Oliver, 1993; Richins, 1997) have attempted to better understand the definition by focusing on the characteristics of the emotions involved. Affective response to certain situations is one of the most clearly described emotional characteristics (Clore, Ortony, \& Foss, 1987; Ortony et al., 1988). This perspective views consumption emotion as a set of affective responses that a customer experiences while consuming products and services (Richins, 1997). Consumption emotion thus is the customer's affective response to the consumption value achieved based on perceived product and service attributes (Mano \& Oliver, 1993; Oliver, 1993; Richins, 1997). Words such as happiness, anger, and fear can be used to describe customer affective state during consumption (Havlena \& Holbrook, 1986; Jang \& Namkung, 2009).

In summary, consumption emotion is the response customers generate from their experience of consuming products and services.

\subsubsection{Classification of Consumption Emotion}

The most prevalent classifications of consumption emotion in the current literature are as follows: (a) the PANAS model (Watson, Clark, \& Tellegen, 1988), (b) the PAD model developed by Mehrabian and Russell (1974) (Lutz \& Kakkar, 1975; Donovan \& Rossiter, 1982; Holbrook, Chestnut, Oliva, \& Greenleaf, 1984), and (c) Izard's (1977) four-dimensional classification.

The PANAS model classifies customer feelings as positive affect and negative affect. Positive emotions include active, calm, alive, peaceful, cheerful, warmhearted, delighted, happy, joyous, relaxed, lighthearted, restful, pleased, stimulated, and excited. Meanwhile, negative emotions include critical, depressed, disgusted, offended, skeptical, sad, upset, and distressed. However, the ambiguity of certain emotions makes classifying emotions as positive or negative problematic. Empirical researchers in service marketing often find it difficult to differentiate positive and negative customer emotions (Babin \& Griffin, 1998)

Russell (1974) illustrated customer emotion using two categorical dichotomies of (1) pleasant/unpleasant and (2) arousing/Sleepy.

By integrating the dimension arousing/soothing into the pleasant-unpleasant model, Russell (1974) more accurately described the various customer feelings. Havlena and Holbrook (1986) compared the reliability, internal validity and external validity of the two models and found Russell's model better suited to consumption emotion study. However, Russell's model does not reflect customer affective responses to external stimuli. Hence, Mehrabian (1980) developed the Pleasure-Arousal-Dominance scale (PAD scale) based on Russell's model. PAD measures pleasure and arousal states stimulated by external factors instead of consumption emotion itself. The PAD scale also gauges intrinsic rather than positive/negative feelings.

The above review demonstrates that arousal is not classifiable as either a positive or a negative emotion. Accordingly, Izard (1977) classified emotions using a four-dimensional taxonomy, namely pleasantness, tension, excitement and assurance. Izard further categorized emotions into three types: positive, negative and neutral.

\section{Research Framework and Hypotheses}

\subsection{Research Framework}

No model exists for the relationship among personnel service, consumption emotion and patronage intention. However, previous research has improved understanding not only of the constructs themselves, but also of how 
they relate to each other and drive behavior. The existing research indicates that: favorable service quality perceptions improve satisfaction (Totterdel \& Holman, 2003; Söderlund \& Rosengren, 2007); favorable service quality perceptions leads to customer re-purchase behavior (Dubé \& Menon, 2000; Netemeyer, Maxham III, \& Pullig, 2005; Kuo, Wu, \& Deng, 2009); and customers with positive emotions display positive behavior, including re-patronage and re-purchase intention (Havlena \& Holbrook, 1986; Baumeister, Vohs, DeWall, \& Zhang, 2007).

Theoretical justification for the above relationships can be found in the appraisal $\rightarrow$ emotional $\rightarrow$ response coping framework developed by Bagozzi \& Lynn (1992) (Gotlieb, Grewal, \& Brown, 1994). Bagozzi and Lynn's (1992) model suggests that the initial service evaluation (i.e., appraisal) leads to an emotional reaction that drives behavior (Figure 1).

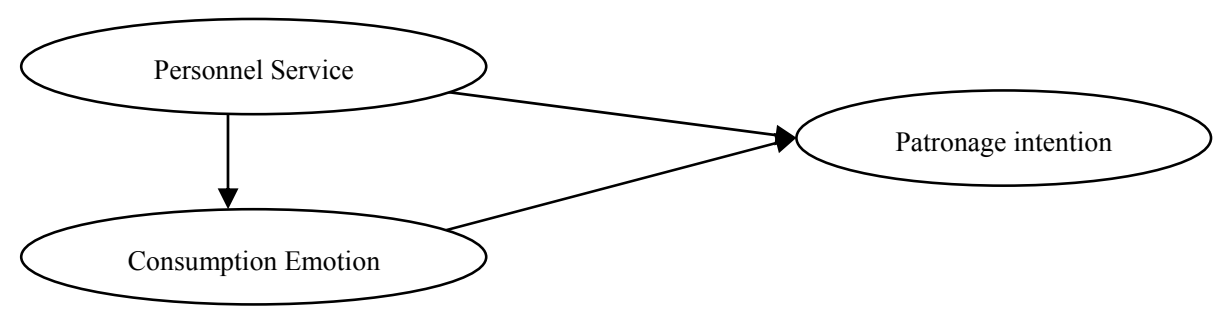

Figure 1. Personnel service, consumption emotion and patronage intention model

According to our preliminary analysis (Hou \& Wu, 2011) that personnel service can be analyzed in terms of assurance, empathy, reflection and tangibility: (1) assurance indicates the knowledge and courtesy of employees and their ability to inspire trust and confidence; (2) empathy indicates the caring, individualized attention that the firm provides customers through its employees; (3) reflection indicates personnel's willingness to help customers and provide prompt services; (4) tangibility indicates the appearance of personnel (Parasuraman, Zeithaml, \& Berry, 1988) (Note 1).

Consumption emotion can be analyzed in terms of happiness, dominance and arousal (Junya, 2005). We assume consumption emotion to be a multi-attribute and uni-polar concept. The various attributes should be gauged separately in measuring consumption emotion. Numerous scholars adopt this view (Westbrook, 1987, 1988; Wirtz \& Bateson, 1999; Wirtz, Mattila, \&Tan, 2000; Walsh, Shiu, Hassan, Michaelidou, \& Beatty, 2011).

\subsection{Hypotheses}

One purpose of retail stores is to enhance the sense of pleasure of in-store customers and encourage their re-patronage intention through reinforcing their relationship with the service provider (Reynolds \& Beatty, 1999). Service procedures, service environment, and interactions between customers and service personnel in the consumption process normally influence customer feelings (Gardner, 1985; Jang \& Namkung, 2009; Ma \& Dubé, 2011). Good service perception increases positive emotions and decreases negative emotions.

The service marketing literature recognizes the importance of interpersonal interaction between customers and service personnel. The quality of this interaction is critical to customer satisfaction (Bitner, Booms, \& Mohr, 1994). Lemmink and Mattsson (2002) studied the relationship between service personnel behavior and customer consumption emotion in the banking, retail, automotive repair, hospital and hotel industries, and showed that the facial expression, behavior, language, and tone displayed by personnel during the service process influence customer consumption emotion. The SERVQUAL service quality scale also emphasizes employees by incorporating employee-related components (e.g., sincerity, courtesy, knowledge, and appearance) that characterize employees who are willing to provide prompt and personal service by understanding and instilling confidence in customers (Zeithaml, Parasuraman, \& Berry, 1990).

Dominance and arousal are always looked on as neutral emotions. This means sometimes they can be looked on as positive emotion and sometimes, on the country, as negative. According to Thyaer's (1989) research, when neutral emotions reach to some too high level that will make person uncomfortable. But, in the retailing context, it seldom happens, because, customers are independent, they will choose to leave if they feel too much neutral emotions.

Accordingly, we hypothesize the following:

H1 Reflection of personnel service is positively associated with the consumption emotions of (a) happiness; (b) dominance; and (c) arousal. 
H2 Empathy of personnel service is positively associated with the consumption emotions of (a) happiness; (b) dominance; and (c) arousal.

H3 Assurance of personnel service is positively associated with the consumption emotions of (a) happiness; (b) dominance; and (c) arousal.

H4 Tangibility of personnel service is positively associated with the consumption emotions of (a) happiness; (b) dominance; and (c) arousal.

The encounter between service personnel and customers is called 'personalization' (Mittal \& Lassar, 1996). The language, behavior, demeanor, and even appearance of service personnel affect customer behavior, including their purchasing decisions and approach/avoidance intentions. The language and marketing tools employed by service personnel stimulate customer buying behavior and post-purchase behavior (Walsh et al., 2011). Personnel providing good and appropriate service will increase customer intention to stay in the store (Hansen \& Seines, 2002; McColl-Kennedy et al., 2009).

Accordingly, we hypothesize the following:

H5 (a) Assurance; (b) empathy; (c) reflection; and (d) tangibility of personnel service are positively associated with customer patronage intention.

Customers extend their consumption emotion to their recognition of products and related issues and to their decision-making process and shopping behavior (Holbrook \& Hirschaman, 1982; Peterson, Hoyer \& Wilson, 1986). Customer patronage intention is the direct response to in-store perceptions. Such psychological models can elaborate the influence of emotions on customer behavior as M-R. Russell and Mehrabian (1978) discussed the relationships among pleasure, arousal and approach intention. Arousal is the customer's affective response to external stimuli. Customers without purchasing needs, influenced by such stimuli, determine to buy or create a preference, which in turn is reflected by such behaviors as purchase or attention. The M-R model indicates that arousal stimulates approach intention in a pleasant atmosphere and avoidance intention in an unpleasant atmosphere.

The following theoretical hypothesis is proposed based on the M-R model and the strength of the relationship between personnel service and patronage intention.

H6 Consumption emotion significantly affects patronage intention, or at least partially mediates between personnel service and patronage intention, and the consumption emotion of (a) happiness; (b) dominance; (c) arousal are positively related to patronage intention.

Figure 2 shows a structural model of personnel service, consumption emotion and patronage intention with constructs.

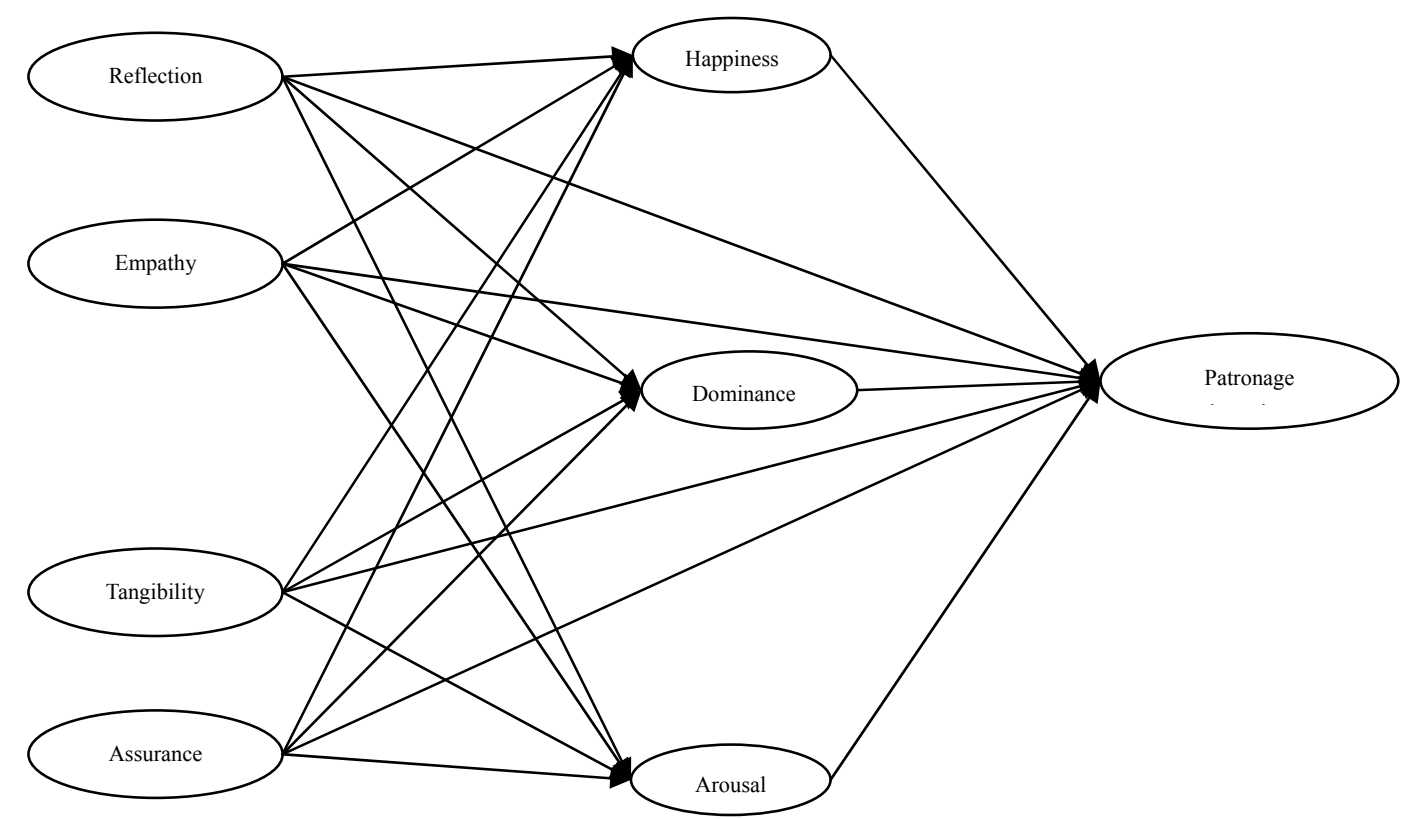

Figure 2. Personnel service, consumption emotion and patronage intention structural model 


\section{Methods}

We chose customers in department stores $\mathrm{D}$ and $\mathrm{P}$ as the research targets (Note 2). We sent out 300 questionnaires and sampled 150 customers of each department. We interviewed customers who just went out from the departments D/P. We took the first person who accepted our interview as sample No.1, and then carried on the interview at 10-person interval to get sample No.2, No.3 .... Sometimes if a customer refused our interview request, then the next customer following shall automatically became a new research target. All 300 questionnaires were returned, for a response rate of $100 \%$, and $298(99.33 \%)$ of the returned questionnaires were valid. Table 1 lists the demographics of the sample.

Table 1. Demographics of samples

\begin{tabular}{lll}
\hline Dimensions & & Result \\
\hline Gender & male & $32.6 \%$ \\
& female & $67.1 \%$ \\
\hline Age & not responding & $0.3 \%$ \\
\hline Education & under 25 & $22.5 \%$ \\
& $25-39$ & $51.7 \%$ \\
& $40-54$ & $20.1 \%$ \\
& over 55 & $5.7 \%$ \\
\hline Family income & under college (not includes college) & $27.9 \%$ \\
& college & $60.1 \%$ \\
& master degree and above & $11.1 \%$ \\
& not responding & $1.0 \%$ \\
\hline & under 2000 yuan & $10.7 \%$ \\
& $2000-3999$ yuan & $31.2 \%$ \\
& $4000-5999$ yuan & $26.9 \%$ \\
& above 6000 yuan & $30.9 \%$ \\
\hline
\end{tabular}

Notes: the Family income is based on the responders' family income per month (including the income of wife/husband, parents), and the unit is RMB.

\subsection{Measurement}

The research variables in the questionnaire were taken from the previous literature, and adjusted to fit the situation of local customers.

The personnel service questionnaire was created through the following steps. First, the personnel service interview questionnaire was developed based on the literature, and then 11 service persons from three different department stores were selected. These service persons were randomly divided into three groups (group one contained five persons, while the other two groups each contained three persons), and group interviews were conducted. Semantic analysis was used to extract interview content related to customer contact, yielding 35 items dealing with personnel service. Second, we discussed these 35 items with department store managers, and adjusted them based on the discussion. This produced an initial questionnaire comprising 39 questions. Third, we interviewed 100 customers who just went out from the Friendship, Mykal, Sunrise, Parkson and Newmart department stores. We use the same process to get our samples as above. The collected data was subjected to preliminary analysis and ambiguous items were changed as appropriate. Fourth, the questionnaire was subjected to a second round of testing. This round involved distributing 200 questionnaires, of which 196 were returned. Factor analysis then obtained four constructs for personnel service, namely assurance, empathy, reflection, and tangibility, and the scale was tested for reliability and validity. After these four steps, the personnel service questionnaire was finally obtained (see Appendix).

The consumption emotion questionnaire was developed based on individual interviews ( 23 subjects interviewed for 10-20 minutes each). Respondents were asked to describe their psychological feelings during shopping, and their responses were consolidated (Table 2). 
Table 2. Emotional interview summary

\begin{tabular}{llll}
\hline Positive & & Negative & \\
\hline Interesting & Happy & Despair & Not fun \\
Funny & Pleasure & Tension & Not good \\
Relaxed & Exciting & Bored & \\
Satisfaction & Ease & & \\
\hline
\end{tabular}

The primary scale for measuring consumption emotion combined Table 2 and the scale of Danyuanshunye (2005) (Note 3). Subsequently, field investigations were conducted in the Friendship, Mykal, Sunrise, Parkson and Newmart department stores, with 250 questionnaires distributed, and 220 valid questionnaires recovered. We interviewed customers who just went out from the departments. We also use the same process to get our samples as above. Factor analysis identified the three constructs of happiness, dominance and arousal for the consumption emotion scale (Hou, 2011). The reliability and validity of the scale were tested to establish the formal consumption emotion questionnaire.

Patronage intention was tested with three questions, namely: (1) I would be very likely to shop in this store; (2) I would be willing to buy merchandise at this store; (3) I would be willing to recommend this store to my friends (Grewal, Baker, Levy, \& Voss, 2003).

\subsection{Measurement Model}

We use the maximum likelihood estimation method to verify the measurement model and path analysis with AMOS 17.0. The results were as follows: $\chi^{2} / \mathrm{df}=814.634 / 320=2.55<5$, root mean square error of the approximation $(\mathrm{RMSE})=0.072<0.08$, comparative fit index $(\mathrm{CFI})=0.913$, normed fit index $(\mathrm{NFI})=0.865$, incremental fit index $(\mathrm{IFI})=0.914$, goodness of fit index $(\mathrm{GFI})=0.840$, and adjusted goodness of fit index $(\mathrm{AGFI})=0.802$. All the indexes exceeded 0.80 , meeting the respective minimum criteria and showing good fitness for the data and theoretical model (Bagozzi \& Yi, 1988).

To ensure the suitability of constructs and data for further analysis, we tested the internal consistency reliability, convergent validity and discriminant validity of the measurement model before conducting the path analysis (Appendix). Internal consistency reliability was tested by Cronbach $\alpha$, where the value should exceed 0.7. Convergent validity was tested using average variance extracted (AVE) and composite reliability (CR), where the AVE value should exceed 0.5 and the CR value should exceed 0.7 (Fornell \& Larcker, 1981), which indicates favorable convergent validity between the constructs. Discriminant validity was tested by comparing the square root of AVE with the correlation coefficient between the constructs. If the former exceeds the latter then desirable discriminant validity exists between the two constructs.

The results in Appendix reveal that the measurement model used in this study has good internal consistency reliability, convergent validity and discriminant validity. The only issue is that the correlation coefficient between assurance and empathy is bigger than the square root of AVE. Table 3 lists descriptive statistics and correlations for all variables.

Table 3. Descriptive statistics and correlations

\begin{tabular}{|c|c|c|c|c|c|c|c|c|c|c|}
\hline Construct & Mean & $\mathrm{SD}$ & 1 & 2 & 3 & 4 & 5 & 6 & 7 & 8 \\
\hline 1. assurance & 3.733 & .654 & .823 & & & & & & & \\
\hline 2. empathy & 3.650 & .655 & $.759^{* *}$ & .738 & & & & & & \\
\hline 3. reflection & 3.708 & .681 & $.708^{* *}$ & $.686^{* *}$ & .774 & & & & & \\
\hline 4. tangibility & 3.721 & .633 & $.647^{* *}$ & $.636^{* *}$ & $.553^{* *}$ & .780 & & & & \\
\hline 5. happiness & 3.226 & .659 & $.706^{* *}$ & $.599^{* *}$ & $.499^{* *}$ & $.519^{* *}$ & .921 & & & \\
\hline 6. dominance & 3.376 & .608 & $.425^{* *}$ & $.437^{* *}$ & $.365^{* *}$ & $.384^{* *}$ & $.540^{* *}$ & .780 & & \\
\hline 7. arousal & 2.822 & .719 & $.539^{* *}$ & $.492^{* *}$ & $.377^{* *}$ & $.408^{* *}$ & $.726^{* *}$ & $.465^{* *}$ & .855 & \\
\hline 8. CPI & 3.304 & .756 & $.618^{* *}$ & $.543^{* *}$ & $.454^{* *}$ & $.462^{* *}$ & $.723^{* *}$ & $.465^{* *}$ & $.649^{* *}$ & .864 \\
\hline
\end{tabular}

Notes: Coefficient alphas are reported along the diagonal; ${ }^{* *} \mathrm{p}<.01$ (two-tails).

\subsection{Results}

To test the hypotheses, a structural model is estimated and displays respectable fit. Figure 3 illustrates the results (significant paths are indicated in bold). Table 4 summarizes the results. 


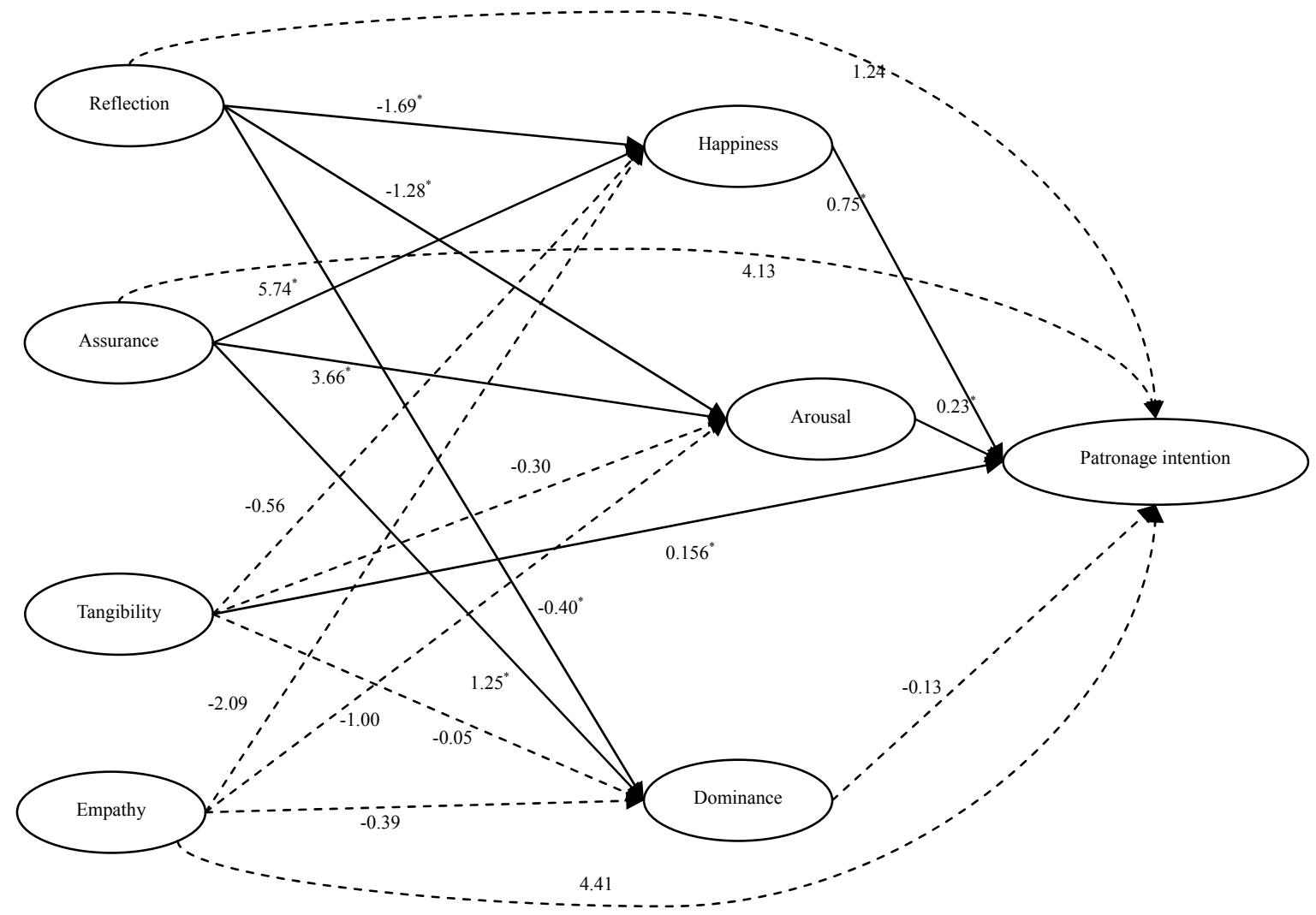

Figure 3. SEM final model

Figure 3 shows the effects of personnel service on consumption emotion, and reveals that the reflection of personnel service significantly influences happiness $(-1.69, \mathrm{p}<0.05)$, arousal $(-0.04, \mathrm{p}<0.05)$ and dominance $(-1.28, \mathrm{p}<0.05)$. Surprisingly however, the influences are negative in all cases. Therefore, hypotheses $\mathrm{H} 1-\mathrm{a}, \mathrm{H} 1-\mathrm{b}$ and H1-c are not supported. Possibly these hypotheses are not supported because previous research involved customers primarily concerned with are "job consumption", meaning quick and timely reflections by service persons are very important. However, in this study, customers are motivated by "joy consumption" and prefer feelings of freedom and individualism. The customers surveyed in this study may feel uncomfortable if service persons reflect too fast. Therefore, personnel service and consumption emotion are significantly related as shown in the model.

Empathy does not significantly affect any dimensions of consumption emotion $(-2.09, \mathrm{p}>0.05 ;-0.39, \mathrm{p}>0.05$; $-1.00, \mathrm{p}>0.05$ ), and thus H2-a, H2-b and H2-c are not supported. The hypotheses may not be supported because the department stores examined in this study standardize service modes. For example, the department stores require their service persons to use uniform greetings and maintain a uniform facial appearance. Customers have difficulty feeling true "humanity" from such standardized service modes. Besides, previous research on service recovery found that when a customer feels negative and unhappy the salesperson should exhibit self-identification and sympathy with the customer's experience to gradually lift the customer's mood (Karatepe, 2006); i.e. empathy is important when customers feel negative emotions. However, this study is focused on department store customers who are seeking happiness, so the influence of empathy is less obvious and the hypotheses are not supported.

Tangibility does not significantly influence any dimensions of consumption emotion $(-0.56, \mathrm{p}>0.05 ;-0.05$, $\mathrm{p}>0.05 ;-0.30, \mathrm{p}>0.05$ ), and so H4-a, H4-b and H4-c are not supported. The hypotheses are not supported because tangibility belongs to the basic evaluation criteria. Bitner, Booms, and Tetreault (1990) posited that service persons with untidy outlook (such as dress) will cause customers to feel uncomfortable and develop negative perceptions of the service personnel. Based on Herzberg's Motivation-Hygiene Theory, we believe that salespersons in department stores perform well in this respect and avoid negative customer appraisals. However, the existing high level of performance in this dimension means that improved performance contributes little to positive customer emotions. 
Assurance significantly and positively affects happiness $(5.74, \mathrm{p}<0.05)$, arousal $(3.66, \mathrm{p}<0.05)$ and dominance $(1.25, \mathrm{p}<0.05)$. Therefore, $\mathrm{H} 3-\mathrm{a}, \mathrm{H} 3-\mathrm{b}, \mathrm{H} 3-\mathrm{c}$ are supported.

Reflection (1.24, $\mathrm{p}>0.05)$, empathy $(1.41, \mathrm{p}>0.05)$ and assurance $(-4.13, \mathrm{p}>0.05)$ do not directly influence patronage intention. Therefore, H5-a, H5-b, H5-c are not supported. However, tangibility $(0.16, \mathrm{p}<0.05)$ directly and positively influences patronage intention, and so H5-d is supported. Happiness $(0.75, \mathrm{p}<0.05)$ and arousal $(0.23, \mathrm{p}<0.05)$ positively influence patronage intention, and therefore H6-a and H6-c are supported. Dominance $(-0.13, p>0.05)$ does not obviously influence patronage intention, and thus H6-b is not supported.

Table 4. Results of Structural Equations Analyses

\begin{tabular}{|c|c|c|c|c|c|c|}
\hline Path & & Estimate & S.E. & t-Value & $\mathrm{p}$ & Hypothesis ${ }^{*}$ \\
\hline \multirow[t]{4}{*}{ reflection $\rightarrow$} & happiness & -1.69 & 0.67 & -2.54 & 0.01 & Rejected (-) \\
\hline & dominance & -0.40 & 0.17 & -2.38 & 0.02 & Rejected (-) \\
\hline & arousal & -1.28 & 0.38 & -3.34 & $* * *$ & Rejected (-) \\
\hline & patronage intention & 1.24 & 2.09 & 0.59 & 0.55 & N.S. \\
\hline \multirow[t]{4}{*}{ empathy $\rightarrow$} & happiness & -2.09 & 1.23 & 1.70 & 0.09 & N.S. \\
\hline & dominance & -0.39 & 0.27 & -1.44 & 0.15 & N.S. \\
\hline & arousal & -1.00 & 0.64 & -1.52 & 0.13 & N.S. \\
\hline & patronage intention & 1.41 & 2.46 & 0.58 & 0.57 & N.S. \\
\hline \multirow[t]{4}{*}{ assurance $\rightarrow$} & happiness & 5.74 & 2.00 & 2.88 & $* * *$ & Accepted $(+)$ \\
\hline & dominance & 1.25 & 0.39 & 3.20 & $* * *$ & Accepted (+) \\
\hline & arousal & 3.66 & 0.87 & 4.22 & $* * *$ & Accepted (+) \\
\hline & patronage intention & -4.13 & 7.01 & -0.59 & 0.57 & N.S. \\
\hline \multirow{4}{*}{ tangibility $\rightarrow$} & happiness & -0.56 & 0.41 & -1.36 & 0.17 & N.S. \\
\hline & dominance & -0.05 & 0.11 & -0.46 & 0.65 & N.S. \\
\hline & arousal & -0.30 & 0.27 & -1.12 & 0.26 & N.S. \\
\hline & patronage intention & 0.16 & 0.07 & 2.11 & 0.04 & Accepted (+) \\
\hline happiness $\rightarrow$ & patronage intention & 0.75 & 0.10 & 7.77 & $* * *$ & Accepted (+) \\
\hline dominance $\rightarrow$ & patronage intention & -0.13 & 0.14 & -0.93 & 0.35 & N.S. \\
\hline arousal $\rightarrow$ & Patronage intention & 0.23 & 0.06 & 3.68 & $* * *$ & Accepted (+) \\
\hline
\end{tabular}

Notes: ${ }^{* * *}<<0.01$. Accepted means the hypothesis is significant; Rejected means the hypothesis is significant but has opposite direction; N.S. means the hypothesis is insignificant. Symbol in the brackets means the direction; + means the direction is positive; - means the direction is negative.

Table 5 lists the estimated value, standard error and " $t$ " value of indirect effect for the results. Figure 6 shows that the happiness and arousal aspects of consumption emotion completely mediate the effect of reflection and assurance on patronage intention, supporting H-6.

Table 5. Direct and indirect effects for the final model

\begin{tabular}{|c|c|c|c|c|c|c|c|c|c|c|c|c|c|c|c|}
\hline \multirow{3}{*}{ Construct } & \multicolumn{12}{|c|}{ Direct effect } & \multirow{2}{*}{\multicolumn{3}{|c|}{$\begin{array}{l}\text { Indirect effect } \\
\text { Patronage intention }\end{array}$}} \\
\hline & \multicolumn{3}{|l|}{ happiness } & \multicolumn{3}{|l|}{ arousal } & \multicolumn{3}{|c|}{ dominance } & \multicolumn{3}{|c|}{ patronage intention } & & & \\
\hline & estimate & S.E. & t-Value & estimate & S.E. & $\mathrm{t}$-Value & estimate & S.E. & t-Value & estimate & S.E. & $\mathrm{t}$-Value & estimate & S.E. & t-Value \\
\hline reflection & -2.006 & 0.060 & -3.922 & -1.802 & 0.028 & -4.177 & -0.522 & 0.014 & -2.719 & -1.913 & 0.003 & 3.684 & -1.913 & 0.003 & 3.684 \\
\hline assurance & 3.133 & 0.063 & 5.184 & 2.800 & 0.029 & 5.460 & 0.835 & 0.015 & 3.629 & 2.984 & 0.002 & 7.769 & 2.984 & 0.002 & 7.769 \\
\hline tangibility & 0.000 & - & - & 0.000 & - & - & 0.000 & - & - & 0.156 & 0.002 & 2.106 & 0.000 & 0.002 & 2.106 \\
\hline
\end{tabular}

To study whether customer characteristics affect customer perceptions of personnel service and consumption emotion, this study used demographic variables as a classified variable for t-value testing of individual samples, and analyzed whether perceptions of personnel service and consumption emotion differ in different classifications.

Table 6 shows that customers' appraisals of personnel service differ with their individual characteristics. Specifically, females generally rate personnel service more highly than males, especially on reflection, showing that males are more rational customers and rate personnel service more neutrally. Regarding age, older customers rate personnel service slightly higher than younger customers, but the differences in each dimension are minimal. This shows that different age groups do not differ significantly in their perceptions of personnel service. Regarding income, customers with high monthly income rate personnel service more highly than those with low monthly income, showing that high income customers are more sensitive to personnel service. Regarding patronage frequency, customers with high patronage frequency rate personnel service much more highly than 
customers with low patronage frequency, supporting the hypothesis that patronage intention increases with perceived personnel service.

Table 6. Personnel service in different categorical variables independent sample T-test

\begin{tabular}{|c|c|c|c|c|c|c|c|c|c|}
\hline \multirow[t]{2}{*}{ Personnel service } & & \multicolumn{2}{|c|}{ Gender } & \multicolumn{2}{|l|}{ Age } & \multicolumn{2}{|c|}{ Monthly family income } & \multicolumn{2}{|c|}{ Patronage times } \\
\hline & & Male & Fmale & Low & High & Low & High & Low & High \\
\hline \multirow[t]{3}{*}{ reflection } & mean & 3.53 & 3.79 & 3.68 & 3.78 & 3.59 & 3.79 & 3.66 & 3.77 \\
\hline & S.D. & 0.77 & 0.62 & 0.66 & 0.73 & 0.71 & 0.65 & 0.67 & 0.69 \\
\hline & $\mathrm{t}$ & -3.09 & & -1.07 & & -2.52 & & -1.31 & \\
\hline \multirow[t]{3}{*}{ assurance } & mean & 3.65 & 3.78 & 3.72 & 3.76 & 3.65 & 3.79 & 3.64 & 3.87 \\
\hline & S.D. & 0.67 & 0.64 & 0.62 & 0.74 & 0.67 & 0.64 & 0.69 & 0.57 \\
\hline & $\mathrm{t}$ & -1.60 & & -0.41 & & -1.88 & & -3.07 & \\
\hline \multirow[t]{3}{*}{ empathy } & mean & 3.56 & 3.69 & 3.63 & 3.72 & 3.58 & 3.70 & 3.58 & 3.75 \\
\hline & S.D. & 0.74 & 0.61 & 0.67 & 0.62 & 0.69 & 0.63 & 0.68 & 0.60 \\
\hline & $\mathrm{t}$ & -1.62 & & -1.07 & & -1.45 & & -2.12 & \\
\hline \multirow[t]{3}{*}{ tangibility } & mean & 3.64 & 3.76 & 3.68 & 3.83 & 3.69 & 3.74 & 3.66 & 3.80 \\
\hline & S.D. & 0.70 & 0.60 & 0.64 & 0.62 & 0.67 & 0.61 & 0.62 & 0.65 \\
\hline & $\mathrm{t}$ & -1.57 & & -1.71 & & -0.65 & & -1.89 & \\
\hline Sample size & $\mathrm{n}$ & 97 & 200 & 221 & 77 & 125 & 172 & 177 & 121 \\
\hline
\end{tabular}

We divide the respondents into two age groups using 39 years of age as a marker. The two groups are named the younger age group (39 years old and under) and the older age group (over 39 years old). As for household income, families with monthly income below $4000 \mathrm{RMB}$ are assigned to the lower income group and those with monthly income above $4000 \mathrm{RMB}$ are assigned to the higher income group. Finally, respondents are grouped according to visit times, with those who visit the store less than three times per month belonging to the lower visit frequency group and those who visit the store more than three times per year belonging to the higher visit frequency group. The t-value is the standardized outcome based on the statistical test of variance equality.

Table 7 shows that customer appraisals of their perceptions of consumption emotion differ according to their individual characteristics. Specifically, females and males clearly differ in their perceptions of arousal, and females have slightly higher perceptions of happiness and arousal than males. This indicates that male customers are more rational than female customers, matching common observations in daily life. Regarding age, older customers exhibit higher perceptions of consumption emotion than younger customers do, but the differences are not significant. Regarding income, no obvious differences exist between the higher and lower income groups, showing that income does not significantly influence perception of emotions. Regarding patronage frequency, high frequency shoppers display clearly higher perceptions of consumption emotion than low frequency shoppers do, supporting the hypothesis that patronage intention increases with consumption emotion.

Table 7. Consumption emotion in different categorical variables independent sample T-test

\begin{tabular}{|c|c|c|c|c|c|c|c|c|c|}
\hline \multirow[t]{2}{*}{ Consumption emotion } & & \multicolumn{2}{|c|}{ Gender } & \multicolumn{2}{|l|}{ Age } & \multicolumn{2}{|c|}{ Monthly family income } & \multicolumn{2}{|c|}{ Patronage times } \\
\hline & & Male & Fmale & Low & High & Low & High & Low & High \\
\hline \multirow[t]{3}{*}{ happiness } & mean & 3.12 & 3.28 & 3.20 & 3.29 & 3.20 & 3.25 & 3.07 & 3.45 \\
\hline & S.D. & 0.74 & 0.61 & 0.63 & 0.73 & 0.69 & 0.64 & 0.64 & 0.62 \\
\hline & $\mathrm{t}$ & -1.88 & & -1.05 & & -0.66 & & -5.09 & \\
\hline \multirow[t]{3}{*}{ arousal } & mean & 2.69 & 2.88 & 2.78 & 2.94 & 2.86 & 2.79 & 2.69 & 3.02 \\
\hline & S.D. & 0.72 & 0.71 & 0.71 & 0.73 & 0.80 & 0.66 & 0.66 & 0.76 \\
\hline & $\mathrm{t}$ & -2.07 & & -1.67 & & 0.73 & & -4.07 & \\
\hline \multirow[t]{3}{*}{ dominance } & mean & 3.39 & 3.37 & 3.35 & 3.44 & 3.36 & 3.39 & 3.29 & 3.50 \\
\hline & S.D. & 0.61 & 0.61 & 0.62 & 0.57 & 0.74 & 0.49 & 0.55 & 0.66 \\
\hline & $\mathrm{t}$ & 0.32 & & -1.05 & & -0.32 & & -2.95 & \\
\hline Sample size & $\mathrm{n}$ & 97 & 200 & 221 & 77 & 125 & 172 & 177 & 121 \\
\hline
\end{tabular}

We divide the respondents into two age groups using 39 years of age as a marker. The two groups are named the younger age group (39 years old and under) and the older age group (over 39 years old). As for household income, families with monthly income below 4000 RMB are assigned to the lower income group and those with monthly income above $4000 \mathrm{RMB}$ are assigned to the higher income group. Finally, respondents are grouped according to visit times, with those who visit the store less than three times per month belonging to the lower visit frequency group and those who visit the store more than three times per year belonging to the higher visit 
frequency group. The t-value is the standardized outcome based on the statistical test of variance equality.

\section{Discussion}

\subsection{Conclusions}

This study used SEM to test how customers' perceptions of personnel service influence their consumption emotion, and further affect their patronage intention. We reached the following conclusions:

(1) Customers' perceptions of reflection and assurance significantly influence their consumption emotion. Figure 6 indicates that reflection and assurance significantly influence happiness, dominance and arousal. Reflection has a negative influence, showing that customer consumption emotion reduces as they perceive increasing reflection from service persons. However, as Díaz and Ruíz (2002) pointed out, customers feel unhappy if a service provider fails to promptly provide a requested service. Understanding the negative influence of reflection can help make useful observations regarding department stores. For example, since customers visit department stores to relax they need individual space and may feel unhappy if service persons are excessively attentive. In contrast to reflection, assurance has a positive influence, proving that customers appreciate the feeling of security that service persons create. Additionally, tangibility does not significantly influence consumption emotion, but does significantly influence patronage intention. This indicates that tangibility does not stimulate customer consumption emotion, but can influence patronage behavior.

Notably, empathy of personnel service does not significantly affect customer consumption emotion and patronage intention. Many scholars have mentioned that individual differences between service persons moderate customer consumption emotion and patronage intention. However, we found empathy to have no obvious effect on customer behavior when correlated with individual service person quality.

(2) Happiness and arousal significantly and positively influence patronage intention, as shown in Figure 6. Therefore, department stores can promote patronage intention by strengthening customer perceived happiness and arousal. Additionally, dominance of consumption emotion does not obviously influence patronage intention. This finding is slightly unexpected given that customers mentioned both "self-perception" and "feeling of freedom" during interviews and thus revealed intense self-perception. This study finds no suggestion that dominance influences patronage intention. First, customers' understanding of dominance may differ from theoretical definitions, affecting the accuracy of model testing. Second, dominance does not affect patronage intention because customers have high willingness to express their own ideas. For example, when salespeople provide suggestions, customers typically express their own points of view regarding the purchase, instead of being influenced by the salesperson. The interviews demonstrate this point.

(3) Consumption emotion mediates between personnel service and patronage intention. This result supplements the theoretical research on consumption emotion and patronage intention. While previous studies emphasized the diversity of consumption emotion, most used consumption emotion as an independent variable, or measured it using "satisfaction" (Babin et al., 2005), approaches that cannot adequately explain the complex behavior of modern customers. This result thus not only enriches the interpretation of customer intentions, but also has practical management implications for department store operators.

\subsection{Practical Suggestions for Department Store Management}

Department stores face increasing competitive pressure, with rising real estate costs and the rapid development of online shopping posing particular threats. Simultaneously, customer diversity and variability add to the challenges. How to understand customers and improve sales instruments has become an important task for the management of department stores. Accordingly, this study demonstrated a method for analyzing personnel service, and provides operational guidance to the management of department stores as follows: First, management of personnel service cannot be superficial. The results of this study suggest that department stores should focus initially on assurance and tangibility. However, stimulating customer perceptions via tangibility is not easy, and so department stores should instead focus on assurance. Specifically, they should seek to enhance the feeling of security that customers derive from service persons. Department stores should attempt to make customers trust and rely on service persons, stimulating positive consumption emotion perceptions and patronage intention.

Reflection demands special attention. Since department store customers seek the feeling of happiness, service persons must not be too active in offering service and yet must provide service when asked. Failure to achieve this balance will leave customers feeling either uncomfortable or dissatisfied.

Second, enhancing customer perceptions of consumption emotion should be a focus of department stores seeking to increase customer patronage intention. The results of this study clearly demonstrated the importance of 
perceptions of consumption emotion to customers today. To enhance consumption emotion, department stores can start by reinforcing personnel service.

Third, department stores should provide different ways of experiencing consumption emotion according to customer characteristics. For example, department stores can strengthen the consumption emotion of female, older or higher income customers, who have stronger perceptions of personnel service, by using the effect of personnel service on these customer groups to enhance their perceptions of consumption emotion.

\subsection{Limitations and Future Research Directions}

Although this study investigated an authentic retail setting involving actual customers, the results should be interpreted with the following limitations in mind.

First, only a limited number of customer features were considered. This study only considered demographic characteristics, and no detailed analysis was conducted regarding the influence of customer characteristics, especially shopping experiences. Future research should include more customer characteristics.

Second, this study extended past research on consumption emotion classification and analysis. However, consumption emotion varies across different studies. Taking customer VIP emotion as an example, this study found that department stores use membership cards, such as regular cards, silver cards and platinum cards, with different incentives. According to Pullman and Gross (2004), customers may generate different emotions towards the VIP status endorsed in membership cards. Customers in whom the VIP emotion is established may exhibit increased loyalty. Future research thus should categorize emotions into basic consumption emotion and VIP consumption emotion.

\section{Acknowledgements}

Supported by China Postdoctoral Science Foundation, 2012M520312; and National Natural Science Foundation of China, 71072011.

\section{References}

Babin, B. J., \& Griffin, M. (1998). The nature of satisfaction: an updated examination and analysis. Journal of Business Research, 41(2), 127-136. http://dx.doi.org/10.1016/S0148-2963(97)00001-5

Babin, B. J., Lee, Y. K., Kim, E. J., \& Griffin, M. (2005). Modeling consumer satisfaction and word-of-mouth: restaurant patronage in Korea. Journal of Services Marketing, 19(3), 133-139. http://dx.doi.org/10.1108/08876040510596803

Bagozzi, R. P., \& Lynn, W. P. (1992). The self regulation of attitudes, intentions, and behavior. Social Psychology Quarterly, 55(2), 178-204. http://dx.doi.org/10.2307/2786945

Bagozzi, R. P., \& Yi, Y. (1988). On the evaluation of structural equation models. Journal of the Academy of Marketing Science, 16(1), 74-94. http://dx.doi.org/10.1007/BF02723327

Baker, J., Levy, M., \& Grewal, D. (1992). An experimental approach to making retail store environmental decisions. Journal of Retailing, 68(4), 445-460.

Bakewell, C., \& Mitchell, V. W. (2003). Generation Y female customer decision-making styles. International Journal of Retail \& Distribution Management, 31(2), 95-106. http://dx.doi.org/10.1108/09590550310461994

Baumeister, R. F., Vohs, K. D., DeWall, C. N., \& Zhang, L. (2007). How emotion shapes behavior: feedback, anticipation, and reflection, rather than direct causation. Personality and Social Psychology Review, 11(2), 167-203. http://dx.doi.org/10.1177/1088868307301033

Bellizzi, J. A., \& Hite, R. (1992). Environment color, customer feeling, and purchase likelihood. Psychology and Marketing, 9(5), 347-363. http://dx.doi.org/10.1002/mar.4220090502

Bitner, M. J., Booms, B. H., \& Mohr, L. A. (1994). Critical service encounters: the employee's viewpoint. Journal of Marketing, 58(4), 95-106. http://dx.doi.org/10.2307/1251919

Bitner, M. J., Booms, B. H., \& Tetreault, M. S. (1990). The service encounter: diagnosing favorable and unfavorable incidents. Journal of Marketing, 54(1), 71-84. http://dx.doi.org/10.2307/1252174

Broekemier, G., Marquardt, R., \& Gentry, J. W. (2008). An exploration of happy/sad and liked/disliked music effects on shopping intentions in a woman's clothing store service setting. Journal of Service Marketing, 22(1), 59-67. http://dx.doi.org/10.1108/08876040810851969

Chun, C. Y., \& Tamura, A. (1998). Thermal environment and human responses in underground shopping malls 
vs department stores in Japan. Building and Environment, 33(2/3), 151-158. http://dx.doi.org/10.1016/S0360-1323(97)00047-4

Clore, G. L., Ortony, A., \& Foss, M. A. (1987). The psychological foundations of the affective lexicon. Journal of Personality and Social Psychology, 53(4), 751-755. http://dx.doi.org/10.1037/0022-3514.53.4.751

Darian, J. C., Tucci, L. A., \& Wiman, A. R. (2001). Perceived salesperson service attributes and retail patronage intentions. International Journal of Retail \& Distribution Management, 29(5), 205- 213. http://dx.doi.org/10.1108/09590550110390986

Díaz, A. B. C., \& Ruíz, F. J. M. (2002). The consumer's reaction to delays in service. International Journal of Service Industry Management, 13(2), 118-140. http://dx.doi.org/10.1108/09564230210425331

Donovan, R. J., \& Rossiter, J. R. (1982). Store atmosphere: an environmental psychology approach. Journal of Retailing, 58(1), 34-57.

Dubé, L., \& Menon, K. (2000). Multiple roles of consumption emotions in post-purchase satisfaction with extended service transaction. International Journal of Service Industry Management, 11(3), 278-304. http://dx.doi.org/10.1108/09564230010340788

Fan, X. (1999). Interaction process and interaction quality. Nankai Business Review, 1, 8-12.

Fornell, C., \& Larcker, D. F. (1981). Evaluating structural equation models with unobservable variables and measurement error. Journal of Marketing Research, 18(3), 39-50. http://dx.doi.org/10.2307/3151312

Gardner, M. P. (1985). Mood states and customer behavior: a critical review. Journal of Customer Research, 12(3), 281-300.

Gotlieb, J. B., Grewal, D., \& Brown, S. W. (1994). Consumer satisfaction and perceived quality: complementary or divergent constructs? Journal of Applied Psychology, 79(6), 875-885. http://dx.doi.org/10.1037/0021-9010.79.6.875

Grewal, D., Baker, J., Levy, M., \& Voss, G. B. (2003). The effects of wait expectations and store atmosphere evaluations on patronage intentions in service-intensive retail stores. Journal of Retailing, 79(4), 259-268. http://dx.doi.org/10.1016/j.jretai.2003.09.006

Hansen, H., Sandvik, K., \& Seines, F. (2002). When Customers Develop Commitment to the Service Employee: Exploring the Direct and Indirect Effects on the Propensity to Stay. Advances in Customer Research, 29, 494-495.

Havlena, W. J., \& Holbrook, M. B. (1986). The varieties of consumption experience: comparing two typologies of emotion in consumer behavior. Journal of Consumer Research, 13(3), 394-404. http://dx.doi.org/10.1086/209078

Holbrook, K. B., \& Hirschaman, E. C. (1982). The experiential aspects of consumption: customer fantasies, feeling and fun. Journal of Customer Research, 9(2), 132-140.

Holbrook, M. B., Chestnut, R. W., Oliva, T. A., \& Greenleaf, E. A. (1984). Play as a Consumption Experience: The Roles of Emotions, Performance, and Personality in the Enjoyment of Games. Journal of Customer Research, 11(September), 728-739.

Hou, M. (2011). The Relationship of Personnel Service, Consumption Emotion and Customer's Patronage Intention of a Department Store' [D] (Chapter 3). Jilin University, Changchun, China.

Hou, M., \& Wu, X. (2011). Research on the measurement of service element in the department store image. Journal of Business Economics and Management, 226(8), 13-20.

Izard, C. E. (1977). Human Emotions. New York: Plenum Press.

Jang, S., \& Namkung, Y. (2009). Perceived quality, emotions, and behavioral intentions: application of an extended mehrabian-russell model to restaurants. Journal of Business Research, 62(4), 451-460. http://dx.doi.org/10.1016/j.jbusres.2008.01.038

Junya, I. (2005). The construction of retail agglomeration's attraction: an analysis of business concentration's characteristics from cognitive and emotional perspectives. Journal of Commerce, 52(4), 173-194.

Karatepe, O. M. (2006). The effects of selected antecedents on the service recovery performance of frontline employees. The Service industries Journal, 26(1), 39-57. http://dx.doi.org/10.1080/02642060500358795

Kotler, P. (1984). Marketing Management: Analysis, planning, and control. New Jersey: Prentice-Hall, Upper 
Saddle River, NJ.

Kuo, Y. F., Wu, C. M., \& Deng, W. J. (2009). The relationships among service quality, perceived value, customer satisfaction, and post-purchase intention in mobile value-added services. Computers in Human Behavior, 25(4), 887-896. http://dx.doi.org/10.1016/j.chb.2009.03.003

Lemmink, J., \& Mattsson, J. (2002). Employee behavior, feelings of warmth and customer perception in service encounters. International Journal of Retail \& Distribution Management, 30(1), 18-33. http://dx.doi.org/10.1108/09590550210415239

Lovelock, C. H. (1983). Classifying services to gain strategic marketing insights. Journal of Marketing, 47(3), 9-20. http://dx.doi.org/10.2307/1251193

Lutz, R. J., \& Kakkar, P. (1975). The Psychological Situation as a Determinant of Customer Behavior. In Schlinger, M. J., \& Arbor, A. (Eds.), Advances in Customer Research (Vol. 2, pp. 439-453). MI: Association for Customer Research.

Ma, Z., \& Dubé, L. (2011). Process and outcome interdependency in frontline service encounters. Journal of Marketing, 75(3), 83-98. http://dx.doi.org/10.1509/jmkg.75.3.83

Mano, H., \& Oliver, R. (1993). Assessing the dimensionality and structure of the consumption experience: evaluation, feeling, and satisfaction. Journal of Consulting and Clinical Psychology, 20(3), 201-207.

McColl-Kennedy, J. R., Patterson, P. J., Smith, A. K., \& Brady, M. K. (2009). Customer rage episodes: emotions, expressions and behaviors. Journal of Retailing, 85(2), 222-237. http://dx.doi.org/10.1016/j.jretai.2009.04.002

Mehrabian, A. (1980). Basic Dimensions for a General Psychological Theory. Cambridge, MA: MIT Press.

Mehrabian, A., \& Russell, J. (1974). An approach to environmental psychology (pp. 132-135). Cambridge, MA: MIT Press.

Menon, K., \& Dubé, L. (2000). Ensuring greater satisfaction by engineering sales assistant response to customer emotions. Journal of Retailing, 76(3), 285-307. http://dx.doi.org/10.1016/S0022-4359(00)00034-8

Michon, R., Chebat, J. C., \& Turley, L. W. (2005). Mall atmospherics: the interaction effects of the mall environment on shopping behavior. Journal of business research, 58(5), 576-583. http://dx.doi.org/10.1016/j.jbusres.2003.07.004

Mittal, B., \& Lassar, W. M. (1996). The role of personalization in service encounters. Journal of Retailing, 72(1), 95-109. http://dx.doi.org/10.1016/S0022-4359(96)90007-X

Netemeyer, R. G., Maxham III, J. G., \& Pullig, C. (2005). Conflicts in the work-family interface: links to job stress, customer service employee performance, and customer purchase intention. Journal of Marketing, 69(2), 130-143. http://dx.doi.org/10.1509/jmkg.69.2.130.60758

Normann, R. (1984). Service management, strategy and leadership in service businesses. Chicester: Wiley.

Oliver, R. L. (1993). Cognitive, affective, and attribute bases of the satisfaction response. Journal of Customer Research, 20(3), 418-430.

Ortony, A., Clore, G., \& Collins, A. (1988). The Cognitive Structure of Emotions. In Prietula, M. J., \& Carley, K. M. (Eds.), A Computational Model of Trust and Rumor[J/OL]. American Association for Artificial Intelligence. Cambridge, England: Cambridge University Press. http://dx.doi.org/10.1017/CBO9780511571299

Parasuaman, A., Berry, L. L., \& Zeithaml, V. A. (1991). Refinement and reassessment of the SERVQUAL scale. Journal of Retailing, 67(4), 420-450.

Parasuraman, A., Zeithaml, V. A., \& Berry, L. L. (1985). A conceptual model of service quality and its implications for future research. Journal of Marketing, 48(3), 41-50. http://dx.doi.org/10.2307/1251430

Parasuraman, A., Zeithaml, V. A., \& Berry, L. L. (1988). SERVQUAL: a multiple-item scale for measuring consumer perceptions of service quality. Journal of Retailing, 64(Spring), 12-40.

Peterson, R. A., Hoyer, W. D., \& Wilson, W. R. (1986). The role of affect in customer behavior: emerging theories and applications. Lexington, MA: D.C. Health and Company.

Plutchik, R. (1980). Emotion: a psycho evolutionary synthesis. New York: Harper \& Row.

Price, L. L., Amould, J. E., \& Deibler, L. S. (1995). Customers' emotional responses to service encounters: the 
influence of the service provider. International Journal of Service Industry Management, 6(3), 34-63. http://dx.doi.org/10.1108/09564239510091330

Pullman, M. E., \& Gross, M. A. (2004). Ability of experience design elements to elicit emotions and loyalty behaviors. Decision Sciences, 35(3), 551-578. http://dx.doi.org/10.1111/j.0011-7315.2004.02611.x

Reynolds, K. E., \& Beatty, S. E. (1999). Relationship customer typology. Journal of Retailing, 75(4), 509-523. http://dx.doi.org/10.1016/S0022-4359(99)00016-0

Richins, M. (1997). Measuring emotions in the consumption experience. Journal of Customer Research, 24(2), 127-146.

Roland Berger Strategy Consultants. Chinese Customer. (2010).

Shostack, G. L. (1985). Planning the Service Encounter. In John A. Czepiel, Michael R. Solomon, \& Carol F. Surprenant (Eds.), The Service Encounte (pp. 243-254). Lexington, MA: Lexington Books.

Söderlund, M., \& Rosengren, S. (2007). Receiving word-of-mouth from the service customer: an emotion-based effectiveness assessment. Journal of retailing and Consumer Service, 14(2), 123-136. http://dx.doi.org/10.1016/j.jretconser.2006.10.001

Surprenant, C. F., \& Solomon, M. R. (1987). Predictability and personalization in the service encounter. Journal of Marketing, 51(2), 73-80. http://dx.doi.org/10.2307/1251131

Tamura, M. (2007). Distribution Theory (p. 96). Beijing: Mechanical Industry Press.

Teller, C., Reutter, T., \& Schmaltz, P. (2008). Hedonic and utilitarian shopper types and created retail agglomerations. International Review of Retail, Distribution and Consumer Research, 18(3), 283-309. $\mathrm{http}: / / \mathrm{dx}$.doi.org/10.1080/09593960802113877

Totterdell, P., \& Holman, D. (2003). Emotion regulation in customer service roles: Testing a model of emotional labor. Journal of Occupational Health Psychology, 8(1), 55-73. http://dx.doi.org/10.1037/1076-8998.8.1.55

Walsh, G., Shiu, E., Hassan, L. M., Michaelidou, N., \& Beatty, S. E. (2011). Emotions, store-environmental cues, store-choice criteria, and marketing outcomes. Journal Business Research, 64(7), 737-744. http://dx.doi.org/10.1016/j.jbusres.2010.07.008

Wanga, E. S. T. (2009). Displayed emotions to patronage intention: consumer response to contact personnel performance. Service Industries Journal, 29(3), 317-329. http://dx.doi.org/10.1080/02642060701846747

Watson, D., Clark, L. A., \& Tellegen, A. (1988). Development and Validation of Brief Measures of Positive and Negative Affect: the PANAS Scale. Journal of Personality and Social Psychology, 54, 1063-1070. http://dx.doi.org/10.1037/0022-3514.54.6.1063

Westbrook, R. A. (1987). Product/Consumption-based affective responses and postpurchase processes. Journal of Marketing Research, 24(3), 257-270. http://dx.doi.org/10.2307/3151636

Westbrook, R. A., \& Oliver, R. L. (1991). The dimensionality of consumption emotion patterns and customer satisfaction. Journal of Customer Research, 18(1), 84-91.

Wirtz, J., \& Bateson, J. E. G. (1999). Customer satisfaction with services: integrating the environment perspective in services marketing into the traditional disconfirmation paradigm. Journal of Business Research, 44(1), 55-66. http://dx.doi.org/10.1016/S0148-2963(97)00178-1

Wirtz, J., Mattila, A. S., \& Tan, R. L. P. (2000). The moderating role of target-arousal on the impact of affect on satisfaction-an examination in the context of service experiences. Journal of Retailing, 76(3), 347-365. http://dx.doi.org/10.1016/S0022-4359(00)00031-2

Yalch, R. F., \& Spangenberg, E. (1990). Effects of store music on shopping behavior. Journal of Customer Marketing, 7(Spring), 55-63. http://dx.doi.org/10.1108/EUM0000000002577

Yalch, R. F., \& Spangenberg, E. (2000). The effects of music in a retail setting on real and perceived shopping times. Journal of Business Research, 49(2), 139-147. http://dx.doi.org/10.1016/S0148-2963(99)00003-X

Zeithaml, V. A., Parasuraman, A., \& Berry, L. L. (1990). Delivering service quality: balancing customer perceptions and expectations. New York: The Free Press.

\section{Notes}

Note 1. Parasuraman, Zeithaml and Berry $(1985,1991)$ first described these dimensions in relation to service in SERVQUAL, not personnel service. We borrow their nomenclature because its popularity and familiarity can 
improve understanding of the our discussion of Personnel Service.

Note 2. These two stores were chosen for two reasons: first, they are single stores, and are located far from other stores (minimum distance of 500 meters). This helps eliminate the effect of cluster image (Teller \& Reutterer, 2008); second customer perceptions of the atmosphere and exterior of these stores did not differ significantly in pre-testing. This helps eliminate the effects of atmosphere and exterior (Michon, Chebat, \& Turley, 2005). The sample selection criteria help to effectively control cluster image, outside and atmosphere.

Note 3. Danyan's scale was chosen because it measures customers in Japanese retail stores, which are single shops, and so is suitable for our research.

\section{Appendix}

Appendix 1. Results of Convergent Validity Analysis

\begin{tabular}{|c|c|c|c|}
\hline Construct & Item & Standard Factor Loading & $\mathrm{CR}$ \\
\hline \multirow[t]{4}{*}{ assurance } & 1. Service Persons are reliable to Customers & $0.688^{*}$ & 0.821 \\
\hline & 2. Service Persons use courtesy words when speak to Customers & $0.714^{*}$ & \\
\hline & 3. Service Persons are manner friendly to Customers & $0.782^{*}$ & \\
\hline & 4. Service Persons make Customers feel kindness & $0.738^{*}$ & \\
\hline \multirow[t]{3}{*}{ empathy } & 5. Service Persons can pay attention to Customers & $0.617^{*}$ & 0.768 \\
\hline & 6. Service Persons greet the Customers & $0.731^{*}$ & \\
\hline & 7. Service Persons smile to the Customers & $0.818^{*}$ & \\
\hline \multirow[t]{3}{*}{ reflection } & 8. Service Persons response quickly on Customers'questions & $0.700^{*}$ & 0.778 \\
\hline & 9. Service Persons response quickly on my requests & $0.828^{*}$ & \\
\hline & 10.Service Persons have rich knowledge on the merchandise & $0.670^{*}$ & \\
\hline \multirow[t]{3}{*}{ tangibility } & 11. Service Persons are tidy dressed & $0.729^{*}$ & 0.785 \\
\hline & 12. Service Persons are beautiful (smart) & $0.714^{*}$ & \\
\hline & 13. Service Persons are unified dressed & $0.779^{*}$ & \\
\hline \multirow[t]{8}{*}{ happiness } & 14. I feel satisfied & $0.588^{*}$ & 0.905 \\
\hline & 15. I feel pleasant & $0.695^{*}$ & \\
\hline & 16. I feel happy & $0.701^{*}$ & \\
\hline & 17. I have good feelings & $0.679^{*}$ & \\
\hline & 18. I enjoys to the full & $0.858^{*}$ & \\
\hline & 19. I feel spiritual enjoyment & $0.890^{*}$ & \\
\hline & 20. It seems interesting & $0.753^{*}$ & \\
\hline & 21. I don't want to go home & $0.711^{*}$ & \\
\hline \multirow[t]{4}{*}{ dominance } & 22. The same as I imagined & $0.458^{*}$ & 0.800 \\
\hline & 23. I can think by my self & $0.900^{*}$ & \\
\hline & 24. I can hold my self & $0.847^{*}$ & \\
\hline & 25. I feel dominance on the surroundings & $0.577^{*}$ & \\
\hline \multirow[t]{3}{*}{ arousal } & 26. I feel exited & $0.784^{*}$ & 0.798 \\
\hline & 27. I feel agitated & $0.695^{*}$ & \\
\hline & 28. I feel high spirit & $0.781^{*}$ & \\
\hline \multirow[t]{3}{*}{ CPI } & 29. The likelihood that I would shop in this store is very high & $0.905^{*}$ & 0.866 \\
\hline & 30. I would be willing to buy merchandise at this store & $0.787^{*}$ & \\
\hline & 31. I would be willing to recommend this store to my friends & $0.784^{*}$ & \\
\hline
\end{tabular}

Notes: * $\mathrm{t}>1.96, \mathrm{P}<0.05$. CR: composite reliability.

Appendix 2. Results of Discriminate Validity Analysis

\begin{tabular}{lllllllll}
\hline Construct & 1 & 2 & 3 & 4 & 5 & 6 & 7 & 8 \\
\hline 1. assurance & $\mathbf{0 . 7 3 1}$ & & & & & & & \\
2. empathy & $\mathbf{0 . 7 5 9}$ & $\mathbf{0 . 7 2 7}$ & & & & & \\
3. reflection & 0.708 & 0.686 & $\mathbf{0 . 7 3 6}$ & & & & \\
4. tangibility & 0.647 & 0.636 & 0.553 & $\mathbf{0 . 7 4 1}$ & & & \\
5. happiness & 0.706 & 0.599 & 0.499 & 0.519 & $\mathbf{0 . 7 4 0}$ & & $\mathbf{0 . 7 2 0}$ & \\
6. dominance & 0.425 & 0.437 & 0.365 & 0.384 & 0.540 & 0.465 & $\mathbf{0 . 7 5 4}$ & \\
7. arousal & 0.539 & 0.492 & 0.377 & 0.408 & 0.726 & 0.865 & 0.649 \\
8. CPI & 0.618 & 0.543 & 0.454 & 0.462 & 0.723 & 0.465 & \\
\hline
\end{tabular}

Notes: the bold figures in diagonal tables are square roots of AVE, other figures are correlation coefficients between constructs. 